\title{
Selective cauterization of supporting ligaments at Non Descent Vaginal Hysterectomy (NDVH)
}

\author{
Jayaraman Nambiar M.*, Muralidhar V. Pai, Vidyashree Poojary, Rekha Upadhay
}

Department of Obstetrics and Gynecology, Kasturba Medical College, Manipal, Karnataka, India

Received: 10 September 2017

Accepted: 05 October 2017

\section{*Correspondence:}

Dr. Jayaraman Nambiar M.,

E-mail: drramnambiar@gmail.com

Copyright: (C) the author(s), publisher and licensee Medip Academy. This is an open-access article distributed under the terms of the Creative Commons Attribution Non-Commercial License, which permits unrestricted non-commercial use, distribution, and reproduction in any medium, provided the original work is properly cited.

\begin{abstract}
Background: The objective of the study was to study the use of electrocautery selectively for cardinal uterosacral ligament complex during NDVH.

Methods: We performed a series of NDVH where electrocautery was used selectively for the uterosacral cardinal ligament complex. Rest all stumps were clamped, divided and ligated.

Results: We did a series of 21 cases using this technique and found this as a very effective method of doing NDVH. There were no major complications.

Conclusion: Selective use of electrocautery for uterosacral and cardinal ligament complex makes NDVH easy.
\end{abstract}

Keywords: Electrocautery, Hysterectomy, NDVH

\section{INTRODUCTION}

Hysterectomy is a most commonly performed gynaecological operation. Abdominal and laparoscopic route of hysterectomy are associated with higher costs. ${ }^{1}$ Most hysterectomies can be completed with vaginal route. However currently only 25-30 percent of them performed vaginally. ${ }^{2}$ It is a well-established fact that vaginal hysterectomy has less complications and a better post-operative out outcome. ${ }^{3-5}$ Purohit $\mathrm{R}$ has devised a technique where all stumps are secured by means of electrocautery. ${ }^{6}$ Sheth S has suggested that NDVH can be in done all situations like previous caesarean section and larger uteri. ${ }^{7}$ We slightly modified this technique and used electrocautery only for cardinal uterosacral ligament complex. Use of electrocautery for all stumps may cause more charring and tissue destruction. There can be lateral spread of the electrocautery effect and may result in more tissue damage. ${ }^{8}$ We selectively used electrocautery for securing cardinal uterosacral ligament complex. We feel division of cardinal uterosacral ligament complex is the most difficult step in vaginal hysterectomy. Once this is done NDVH becomes easier. We present a new technique where in only uterosacral ligaments are divided after electrocauterization. We have done 21 cases of NDVH using this technique with no complications.

\section{METHODS}

We did a prospective observational study among patients undergoing NDVH using this new technique. Only cases where uterine size is less than 14 weeks of pregnant uterus entered the study. Before surgery a per speculum examination was done and if cervix was visualized easily they entered the study. Cases where cervix was not easily visualized were excluded from the study. The procedure for hysterectomy consisted of the following

- $\quad$ After putting a vaginal speculum, Cervix pulled with a vulsellum. We did not infiltrate saline adrenaline around the cervix

- Vaginal walls were incised both anteriorly and posteriorly with small transverse incision

- Bladder dissected of the cervix 
- Lateral vaginal walls were not incised

- Pouch of Douglas opened after holding it with Allis forceps and cutting it with scissors

- Lateral vaginal wall was clamped cut and ligated

- In the next step the cardinal and uterosacral ligaments were lifted using right-angled forceps and cauterized with bipolar cautery and divided

- UV fold pf peritoneum is opened

- Once this is done there would significant uterine descent and uterine arteries are ligated

- Next ovarian ligaments, round ligaments, and tubal attachment to cornua were clamped, cut and ligated

- If ovaries were to be removed, traction was made on round ligaments and infundibulopelvic ligaments were clamped, cut and ligated

- A stich was taken through Uterosacral ligaments and used to suspend the vaginal apex

- Vaginal wall was closed. (Figure 1-4).

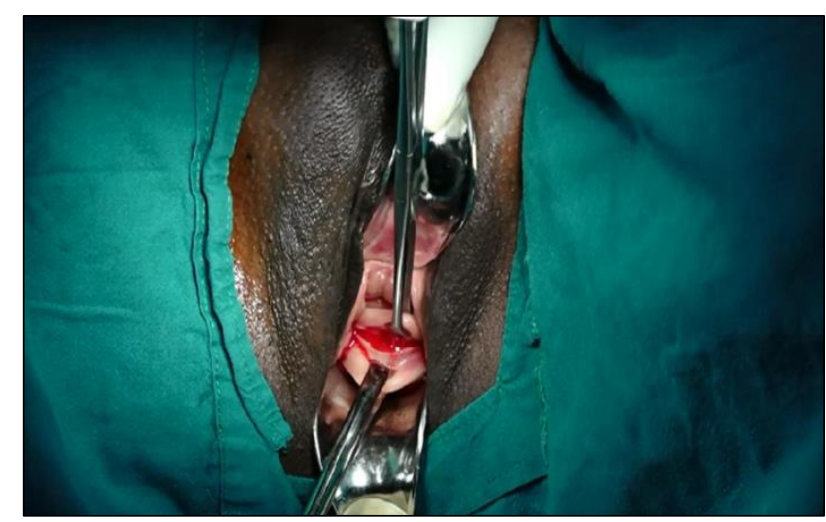

Figure 1: Incision on the anterior vaginal wall.

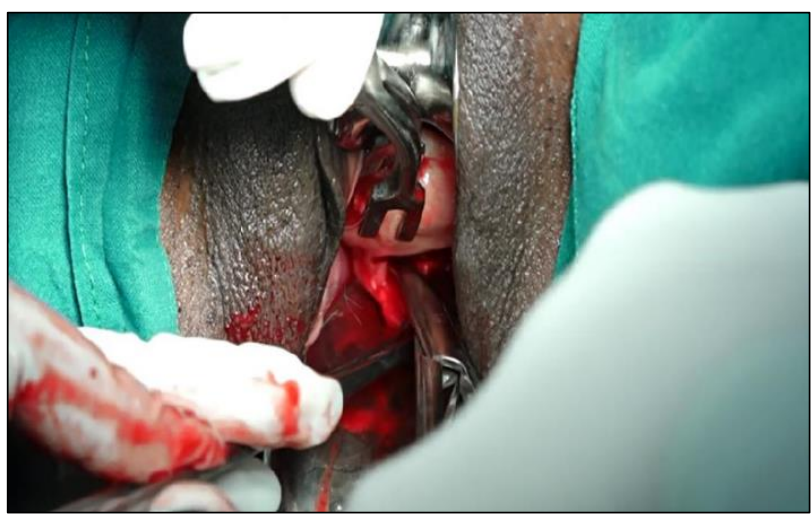

Figure 2: Opening of pouch of Douglas.

In patients with previous caesarean section the bladder was not separated first. Pouch of Douglas was opened first. Lateral vaginal wall is clamped cut and ligated. Uterosacral cardinal ligament complex was cauterized and later divided. After wards, Uterine artery was ligated extra peritoneally. Once this is done bladder was separated first in the lateral space and later central adhesion was divided and bladder pushed up. Afterwards Hysterectomy was done in a standard manner.
In uteri were the size was larger than normal we resorted to bisection for access to upper pedicles. We could remove all Uteri by bisection.

No separate Ethical committee clearance was obtained for the study as use of electrocautery is already in use for hysterectomy. An informed consent was obtained from all patients.

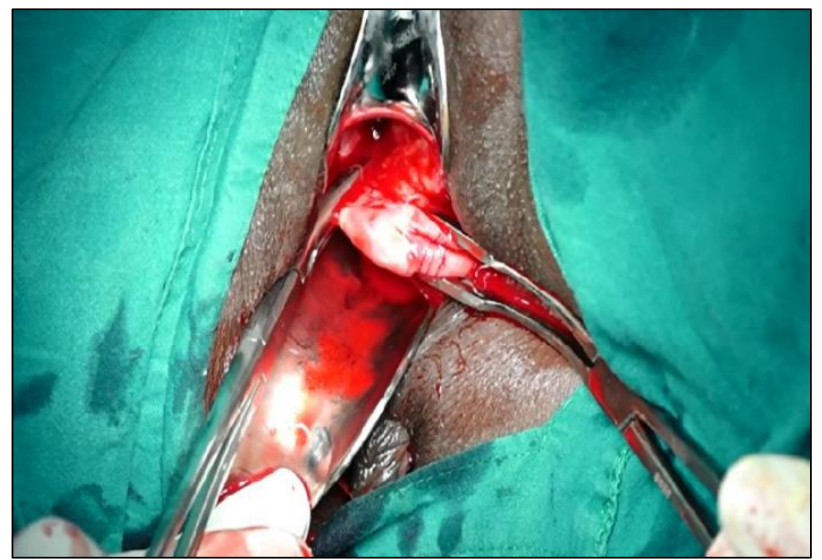

Figure 3: Clamping and division of lateral vaginal wall.

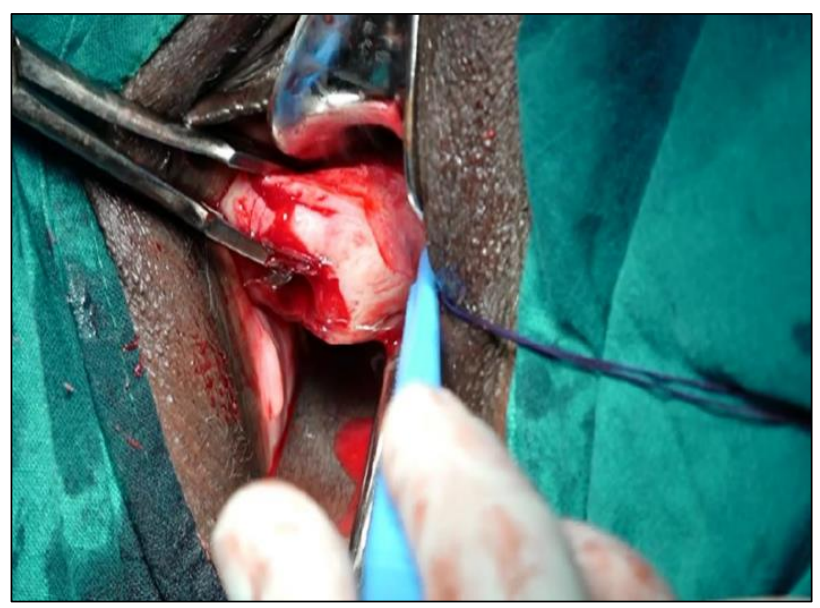

Figure 4: Clamping and division of Uterosacral cardinal ligament complex with electrocautery.

\section{RESULTS}

We did a total of 21 cases using this technique. Only uterus with size less than 14 weeks underwent vaginal hysterectomy in our study. Commonest indication for Hysterectomy was fibroid uterus. Five cases had previous LSCS (Table 1).

Mean operating time was $67.38 \pm 16.77$ minutes. No case needed to be converted to Laparoscopic or abdominal route. Adnexectomy was done in 5 cases. There were no serious intraoperative complications. Blood loss during the surgery was $219.05 \pm 84.37 \mathrm{ml}$. Post-operative blood transfusion was needed only in 3 cases (Table 2). There 
were no significant post-operative complications like post-operative vault haematoma. All the cases were discharged on third postoperative day.

Table 1: Patient characteristics.

\begin{tabular}{|ll|}
\hline Characteristics & $\begin{array}{l}\text { Non-descent vaginal } \\
\text { hysterectomy }(\mathrm{N}=21)\end{array}$ \\
\hline Age in years (Mean \pm SD) & $42.1 \pm 4.7$ \\
\hline Previous LSCS & $\mathrm{n}=5(23 \%)$ \\
\hline Indication for surgery & \\
\hline Fibroid & $\mathrm{n}=12(57.14 \%)$ \\
\hline Abnormal uterine bleeding & $\mathrm{n}=5(9.09 \%)$ \\
\hline Adenomyosis & $\mathrm{n}=4(7.27 \%)$ \\
\hline
\end{tabular}

Table 2: Intraoperative characteristics.

\begin{tabular}{|ll|}
\hline $\begin{array}{l}\text { Operating time in minutes } \\
\text { (Mean } \pm \text { SD) }\end{array}$ & $\begin{array}{l}\text { Non-descent vaginal } \\
\text { hysterectomy }(\mathrm{N}=21)\end{array}$ \\
\hline Blood loss in ml (Mean \pm SD) & $67.38 \pm 16.77$ \\
\hline Blood transfusion post-surgery & $219.05 \pm 84.37$ \\
\hline Uterine weight $(\mathrm{gm}=3)(14.20 \%)$
\end{tabular}

\section{DISCUSSION}

Vaginal hysterectomy is established as the least invasive method of Hysterectomy. Purohith suggested use of right angled forceps to elevate the tissues and electrocauterization for the pedicles to convert difficult hysterectomies into easier one. Purohit technique involved the use of electrocautery for all pedicles. ${ }^{6} \mathrm{We}$ felt that use of electrocautery for all pedicles may cause more tissue charring and tissue destruction. There can be lateral spread during the use of electrocautery which may cause tissue destruction. ${ }^{8}$ By restricting the use of electrocautery just for cardinal-uterosacral ligament complex we can prevent the excessive tissue destruction in cases of NDVH.

Further cauterization of uterine artery may not be a secure method of securing the uterine artery. Purohit had an incidence of vault hematoma of $2 \%$ in his series. ${ }^{6} \mathrm{We}$ secured the uterine artery with ligation and had no incidence of vault hematoma. Vault hematoma following vaginal hysterectomy can be associated with febrile morbidity and increased hospital stay. ${ }^{9}$ Once the uterosacral cardinal ligament complex is divided there will be significant uterine descent and hysterectomy becomes easier. In our technique, only the uterosacral cardinal ligament complex is cauterized and rest of all pedicles are ligated. It was our observation that once uterosacral cardinal ligament complex is divided there will be significant descent and hysterectomy becomes very easy. The uterosacral cardinal ligament complex was elevated with right angled forceps, cauterized and divided. Use of right angled forceps requires less space and does not need skilled assistants. Conventional clamping and division needs more space and skilled assistants.

We did 21 cases and found this technique very easy. We did not infiltrate saline adrenaline solution during NDVH as we could always separate bladder without infiltration. Use of vasopressors during vaginal hysterectomy can give a false sense of security and may contribute to the development of vault haematoma. ${ }^{10}$ This technique can be considered as a modification of the original Purohit technique where all stumps are cauterized and divided. Most NDVH fail because of failure to divide the uterosacral and cardinal ligaments. We used a technique of elevation of uterosacral ligament by right angled forceps and division after electrocauterization. There were no intraoperative or postoperative complications in the present study. We discharged all on patients on third postoperative today. Miskry $\mathrm{T}$ et al also in a study discharged their patients after vaginal hysterectomy on third postoperative day. ${ }^{4} \mathrm{We}$ would suggest that many hysterectomies can be converted into vaginal route using this technique.

\section{CONCLUSION}

Selective use of cautery for uterosacral and cadinal ligament during NDVH makes NDVH very easy.

\section{ACKNOWLEDGMENTS}

Authors would like to thank Ms Latha Shetty, staff nurse, Kasturba Medical College, Manipal for the help provided during the study.

\section{Funding: No funding sources}

Conflict of interest: None declared

Ethical approval: The study was approved by the Institutional Ethics Committee

\section{REFERENCES}

1. Meikle SF, Nugent SW, Oleans M. Complications and recovery from laparoscopy-assisted vaginal hysterectomy compared with abdominal and vaginal hysterectomy. Obstet GynecoI. 1997;89:304-11.

2. Wilcox LS, Koonin LM, Porkas R, Strauss LT, Xia Z, Peterson HB. Hysterectomy in the United States 1988-1990. Obstet Gynecol. 1994;83:549-55.

3. Dicker RC, Greenspan JR, Strauss LT, Cowart MR, Scally MJ, Peterson HB, et al. Complications of abdominal and vaginal hysterectomy among women of reproductive age in the United States. The Collaborative Review of Sterilization. Am J Obstet Gynecol. 1982;144:841-8.

4. Miskry T, Magos A. Randomized, prospective, double-blind comparison of abdominal and vaginal hysterectomy in women without uterovaginalprolapse. Acta Obstet Gynecol Scand. 2003;82:351-8. 
5. Lingman G, Ottosen, L. Three methods for hysterectomy: a randomised, prospective study of short term outcome. $\mathrm{Br} \mathbf{J}$ Obstet Gynaecol. 2000;107:1380-5.

6. Purohit RK. Purohit technique of vaginal hysterectomy: a new approach. $\mathrm{Br} \mathrm{J}$ Obstet Gynaecol. 2003;110:1115-9.

7. Sheth SS. The scope of vaginal hysterectomy. Eur J Obstet Gynecol Reprod Biol. 2004;115:224-30.

8. Baggish MS, Clark J, Firestein S. Thermal ureteral injury secondary to use of the ligasure device during subtotalabdominal hysterectomy. J Gynecol Surg. 2005;21(2):81-7.
9. Thomson AJ, Farquharson RG. Vault haematoma and febrile morbidity after vaginal hysterectomy. Hosp Med. 2000;61:535-8.

10. Oláh K. Vaginal hysterectomy in the absence of prolapse. Obstet Gynaecol. 2005;7:233-40.

Cite this article as: Nambiar JM, Pai MV, Poojary V, Upadhay R. Selective cauterization of supporting ligaments at Non Descent Vaginal Hysterectomy (NDVH). Int J Reprod Contracept Obstet Gynecol 2017;6:5103-6. 